\title{
Application of oxide coatings to metals in electrolyte solutions by microplasma methods( ${ }^{(\cdot)}$
}

\author{
Aleksander Vladimirovich Timoshenko* and Yuliya Vladimirovna Magurova*
}

\begin{abstract}
Microplasma oxidation of aluminium alloys in alkaline colloidal and finely dispersed solutions is analysed. Oxidation causes both electrolyte and alloy components to be incorporated into resultant coatings, which affect the deposition parameters and coating properties. Oxidation process has been studied at spark, micro-arc, and arc stages under an alternating current polarisation and under purely anodic polarisation. It is shown that the cathodic component of the alternating current not only facilitates subsequent anodic process, but also contributes to the formation of an oxide layer.

Keywords Microplasma. Oxidation. Coating. Aluminium. Electrolites.

\section{Aplicación de recubrimientos óxidos a metales en las soluciones de electrólitos mediante métodos de microplasma}

Resumen Se ha examinado la aplicación de procesos de oxidación por microplasma de las aleaciones de aluminio en electrólitos alcalinos, tanto en estado coloidal como microdisperso. Se descubrió que durante el proceso de la oxidación, en la estructura del recubrimiento óxido, van incluyéndose tanto los componentes del electrólito como los de la aleación, lo que modifica las propiedades y parámetros de deposición de las aleaciones obtenidas. El proceso de la oxidación se examinó a lo largo de las siguientes etapas: chispas, micro-arco y arco, tanto bajo la polarización de la corriente alterna como en condiciones de polarización anódica. Se ha demostrado que la componente catódica de la corriente alterna polarizante no sólo facilita los siguientes procesos anódicos, sino que además contribuye a los procesos de formación de la capa óxida.
\end{abstract}

Palabras clave Microplasma. Oxidación. Recubrimiento. Aluminio. Electrólitos.

\section{INTRODUCTION}

When oxidizing metals in electrolyte solutions, bear in mind that there is a limit value of the voltage at the bath. If this value is higher, spark discharges appear on the surface being oxidized. This phenomenon was described in detail by Gunterschulze et al. ${ }^{[1 \text { and } 2]}$. The authors pointed out that this phenomenon deteriorates the properties of the oxide layer. At the same time the later works have shown it is possible to form oxide coatings with high operational properties and for voltages higher than the sparking one. As the spark and arc discharges are concentrated at the surface in sections which do not exceeded several square micrometers in area, it was suggested to call the coating formation processes, at the voltages exceeding the sparking voltage, as microplasma processes.

Microplasma processes were studied for the first time in Russia by G.A.Markov et al. ${ }^{[3]}$. On the base of these studies, a new practice of microplasma application of ceramic and compound coatings was designed. With this practice, it is possible to produce specimens of high mechanical, thermal, corrosion-resisting, antifriction, dielectric, and other properties.

For example, microplasma oxidation improves significantly properties of oxide coatings on valve metals (Table I).

For these, the microplasma oxidation takes place at bath voltages of 200 to $1000 \mathrm{~V}$, therewith field intensity in near-electrode space reaches $10^{7}$. $10^{8} \mathrm{~V} / \mathrm{m}$. High field intensity results in appearing of microplasma discharges on electrode surface.

(•) Trabajo recibido el día 31 de enero de 2000 y aceptado en su forma final el día 7 de septiembre de 2000.

$\left(^{*}\right)$ Moscow Institute of Steel and Alloys (Technological University). Leninskii pr. 4. Moscow 117049 (Russia) 
Table I. Properties of oxide coatings forming by hard anodizing and microplasma oxidizing on 2024 alloy

Tabla I. Comparación de las propiedades de los recubrimientos de óxidos sobre la aleación 2024, hechos mediante oxidación anódica dura y oxidación microplásmica

\begin{tabular}{lcc}
\hline Coating properties & $\begin{array}{c}\text { Hard } \\
\text { anodizing }\end{array}$ & $\begin{array}{c}\text { Microplasma } \\
\text { oxidizing }\end{array}$ \\
\hline Maximum thickness, $\mu \mathrm{m}$ & 60 & $>500$ \\
Microhardness, GPa & $<4$ & $12-16$ \\
Volume porosity, \% & $16-22$ & $7-8$ \\
Electric strength, $\mathrm{V} / \mu \mathrm{m}$ & $10-15$ & $20-60$ \\
Water content in coating, \% & $5-8$ & $<2$ \\
Electrolyte anions content & & \\
in coating, \% & $8-12$ & $<1$ \\
\hline
\end{tabular}

The possibility of application of uniform coatings on intricate surfaces is one of the advantages of this technique. Here, special preliminary treatment of a surface is not demanded. Use of nondeficient, nontoxic, and harmless components in electrolyte solutions is important advantage of the microplasma oxidation proceses. Cost of the microplasma treatment when used simple and low-priced electrolytes is calculated mainly by power consumption of 0.05 to $15 \mathrm{kWh} / \mathrm{dm}^{2}$ depending on thicknes and quality of coatings.

Changing electrolyte composition and electrical modes, may produce complex multicomponent ceramic, metal-ceramic, polymer, and compound coatings of unique set of properties.

At present, a number of works have been devoted to the microplasma processing of metals in electrolyte solutions. However, the coating formation mechanisms, under an alternating current, are not yet completely clear. Its significant differences under the DC, AC, and pulse conditions; the succession of sparkless, spark, micro-arc, and arc stages of oxidation; variable the rectifying properties of a coating during the process; and other issues call for further investigation. At the same time, knowledge on the micro-plasma oxidation mechanism would allow to receive general practice directions for oxidation processes and to predict coatings properties according to formation conditions.

\section{EXPERIMENTAL METHOD}

The samples used were specially prepared $\mathrm{Al}-\mathrm{Cu}$, Al-Mg, Al-Cu-Mg, and Al-Si alloys as well as 2024 industrial alloy. Alloying metals were no less than $99.98 \%$ pure. Heat treatment of the experimental alloys was similar to that used for industrial alloys of nearly the same composition ${ }^{[4]}$. The $\mathrm{Al}-\mathrm{Cu}$ alloys were water-quenched starting from $540^{\circ} \mathrm{C}$ with subsequent aging for $12 \mathrm{~h}$ at $200^{\circ} \mathrm{C}$, the $\mathrm{Al}$ $\mathrm{Cu}-\mathrm{Mg}$ alloys were quenched from $495{ }^{\circ} \mathrm{C}$ and aged for $13 \mathrm{~h}$ at $195^{\circ} \mathrm{C}$, and the Al-Si samples were annealed at $300^{\circ} \mathrm{C}$ for $4 \mathrm{~h}$ and air cooled. In all the specially prepared alloys, primary dopants, $0.7 \pm 0.01 \% \mathrm{Mn}$ were incorporated. The industrial alloys were used in the as received condition.

The experiments were performed on samples with a total area of $8-10 \mathrm{~cm}^{2}$. Aluminium conductors wires of 1,100 alloy were rigidly riveted to the samples. Prior to the application of the coatings, the sample surface was mechanically ground, degreased in ethanol and rinsed in distilled water. The experiments were carried out with electrolytes that contained sodium hydroxide, aluminate and polyphosphate. Analytical and reagent-grade chemicals were dissolved in distilled water.

Figure 1 shows the diagram of an experimental setup for the application of the coatings and investigation of the process. Sample 1 was oxidized in a $3 \mathrm{~L}$ bath 5 made of $12 \mathrm{X} 18 \mathrm{H} 10 \mathrm{~T}$ stainless steel. The bath was cooled by a tap water. Simultaneously, the electrolyte was agitated by mechanical stirrer 4 with an electric motor 8 . The temperature of the electrolyte was measured with a thermistor 3 connected to a digital temperature meter 10.

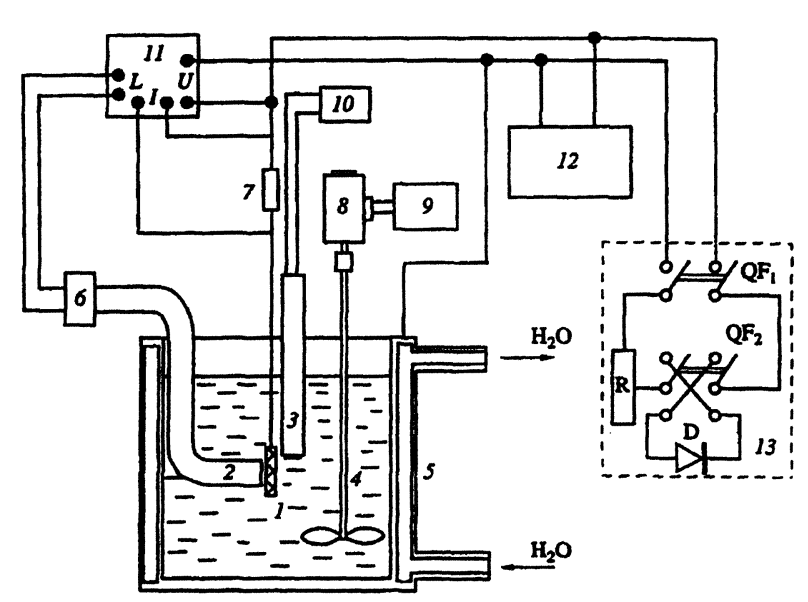

Figure 1. Experimental setup for microplasma coating application (notations are given in the text).

Figura 1. Esquema de la instalación experimental para la aplicación de recubrimientos de microplasma (véanse las anotaciones en el texto del artículo).

Rev. Metal. Madrid 36 (2000) http://revistademetalurgia.revistas.csic.es 
During the oxidation, optical radiation was monitored with light guide 2, which comprised a bent quartz rod of $12 \mathrm{~mm}$ in diameter. One end of the light guide was placed inside the bath near the sample and the other was located in the immediate vicinity of FD-24 photodiode 6 . The signal from the photodiode was directed to the input of an Sl122A oscilloscope.

The bath was powered by power supply 12 connected to an industrial supply line via a $5 \mathrm{~kW}$ step-up transformer. For adjusting output current, the feed circuit of the bath incorporated a number of capacitors (from 2.5 to $80 \mu \mathrm{F}$ ) whose switching made it possible to vary operating current over a wide range.

To control the current shape and bath voltage, S1-122A quadruple-trace oscilloscope 11 was connected to the setup. The current signal went into the oscilloscope through ballast resistor $7(R=$ $0.23 \Omega$ ). The voltage signal passed through a 1:1000 potential divider.

When studying the effect of a polarisation mode, variable-resistance $(R)$ unit 13 was inserted in the feed circuit to vary the anodic or cathodic current from 0 to $100 \%$ of its peak value. The controlled-current direction was changed with a diode $\mathrm{D}$ and switch $\mathrm{QF}_{2}$.

During oxidation, $\mathrm{pH}$ and the optical density $\mathrm{D}$ of the electrolyte were measured, respectively, with a pH 121 instrument and a KFK-2MP photoelectric concentration colorimeter with a light filter having a transmission peak at $315 \pm 5 \mathrm{~nm}$.

The thickness and microhardness were measured from cross-sections on a PMT-3 unit at a magnification of $\times 500$; the diamond indenter was loaded by 50 or $100 \mathrm{~g}$ weights.

The chemical resistance of the coatings was evaluated by the time to coating failure in a solution $300 \mathrm{~g} / \mathrm{L} \mathrm{HCl}+200 \mathrm{~g} / \mathrm{L} \mathrm{CuCl}_{2}$. The onset of failure was determined with a specially designed device from a drastic change in surface potential on those sites of the coating where a drop of the solution was applied. For this purpose, a platinum electrode was inserted into the drop and potential difference across the sample and the platinum electrode was measured.

X-ray diffraction analysis was performed with a diffractometer ( $\mathrm{Cu}$ radiation). The elements were depth-profiled using a scanning microscope with a Link-860 X-ray spectral microanalysis attachment.

The unit for breakdown voltage measurements allowed the voltage to be increased at a maximum rate of $25 \mathrm{~V} / \mathrm{s}$. The probe was a steel $\operatorname{rod} 4 \mathrm{~mm}$ in diameter with a rounded face. The breakdown voltage was measured on a smooth horizontal specimen surface at least $1 \mathrm{~h}$ after deposition and subsequent drying.

The bulk porosity of the coatings was determined using the method filling pores with polyethylsiloxane liquid at $110^{\circ} \mathrm{C}$ and comparing the coating weight before and after the filling.

During oxidation, $\mathrm{pH}$ and the optical density $\mathrm{D}$ of the electrolyte were measured, respectively, with a $\mathrm{pH} 121$ instrument and a KFK-2MP photoelectric concentration colorimeter with a light filter having a transmission peak at $315 \pm 5$ $\mathrm{nm}$.

\section{RESULTS}

Aluminium oxidation by an alternating current proceeds following several stages.

- Sparkless oxide film formation stage. This process is similar to conventional metal anodising in aqueous electrolytes. The bath voltage $U_{a}$, amplitude changes from 0 to spark voltage $U_{\text {sp }}$. In our case, $U_{\text {sp }}=255 \pm 25 \mathrm{~V}$.

- Spark stage. Spark discharges appear after $5 \mathrm{~s}$. Homogeneously distributed small migrating sparks are observed, and $U_{\mathrm{a}}$ increases from $U_{\mathrm{sp}}$ to $400 \mathrm{~V}$. After 10-12 min of oxidation, the discharge pattern varies.

- Micro-arc stage. Uniformly distributed, small bright-white discharges transform to larger yellow-red ones that slowly migrate throughout the surface. The number of the discharges decreases and these become less mobile. $U_{\text {a }}$ increases to 550-570, and $U_{c}$ to $140-180 \mathrm{~V}$. Micro-arc stage lasts 45-60 min.

- Arc stage. Starting from a certain moment, the discharges concentrate on some surface spots; the latter one increases in size. The coatings are partially destroyed; $U_{\mathrm{a}}$ decreases to $500-520 \mathrm{~V}$ and then gradually regains its previous level while $U_{c}$ decreases to 200-230 V and stabilises.

Such a succession of micro-plasma oxidation stages is also observed for direct current.

As can be seen from the table II, spark-formed coatings have the least chemical resistance. When applying a drop of a test solution on the surface, the coating fails in less than a minute and the solution penetrates in to the substrate. This indicates that the spark stage coating has a great number of open pores. 
Table II. Properties of coatings on aluminium

Tabla II. Propiedades de los recubrimientos oxidados sobre el aluminio

\begin{tabular}{cccc}
\hline $\begin{array}{c}\text { Oxidation } \\
\text { time, } \min \end{array}$ & $\begin{array}{c}\text { Coating } \\
\text { thickness, } \mu \mathrm{mm}\end{array}$ & $\begin{array}{c}\text { Chemical } \\
\text { resistance, } \text { min }\end{array}$ & $\begin{array}{c}\text { Bulk porosity, } \\
\text { vol. \% }\end{array}$ \\
\hline 2 & 3 & 0.6 & 23 \\
5 & 7 & 1.0 & 19 \\
10 & 9 & 3.8 & 14 \\
15 & 12 & 8.5 & 10 \\
30 & 21 & 12.6 & 8 \\
60 & 38 & 15.3 & 7 \\
120 & 42 & 12.8 & 8 \\
150 & 44 & 10.1 & 11 \\
\hline
\end{tabular}

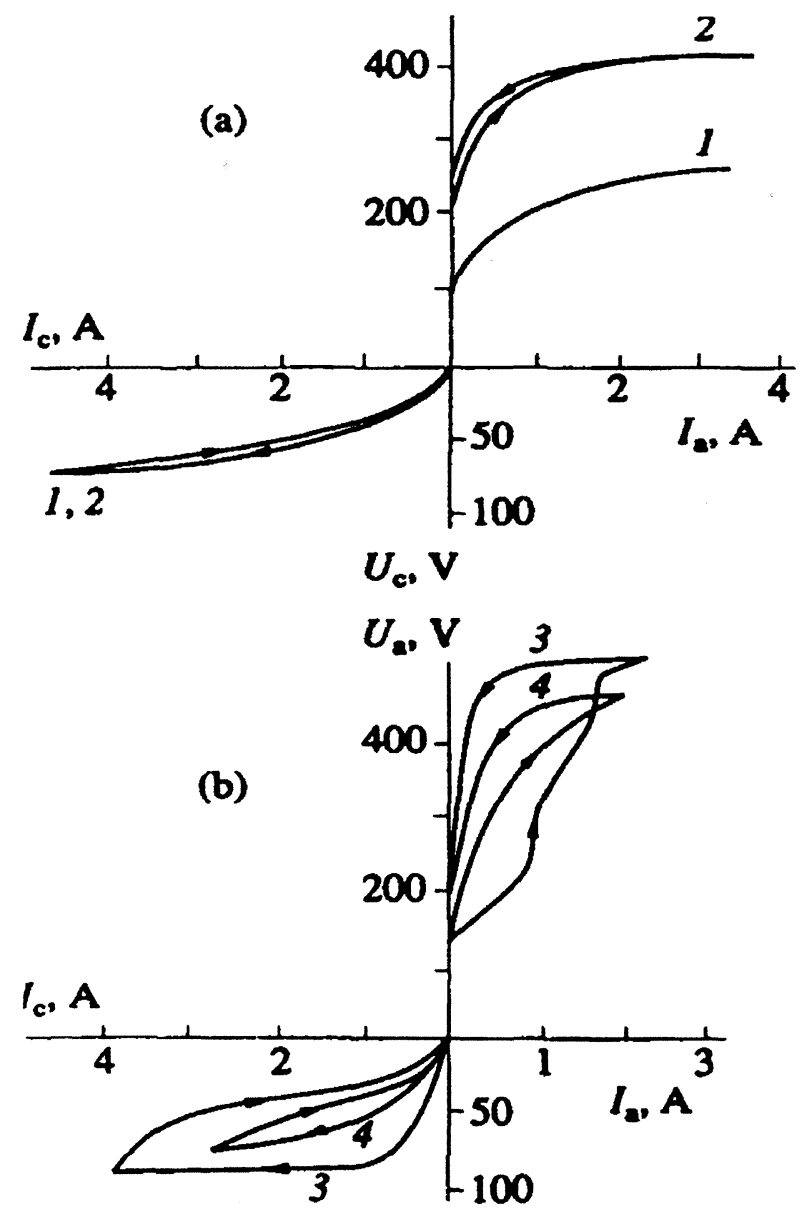

Figure 2. Voltage-current curves for 2024. Oxidation time (1) 0.5, (2) 5 , (3) 60 , and (4) 150 min; modes (a, 1) sparkless, $(a, 2)$ spark, $(b, 3)$ micro-arc, and $(b, 4)$ arc.

Figura 2. Curvas corriente-tensión durante la oxidación de la aleación 2024. Tiempo de oxidación (min): (1) - 0.5; (2) - 5; (3) - 60; (4) - 150. Regímenes: (a, 1) - sin chispas; (a, 2) - con chispas; (b, 3) - micro-arco; (b, 4) - arco.
The variation of the electrical data of the deposition throughout the growth reflects the changes in the electrical resistivity of the oxide layer and its asymmetry. The anodic-to-cathodic voltage amplitude ratio $U_{\mathrm{a}} / U_{\mathrm{c}}$ is more than five at the oxidation onset, but it later decreases.

During spark oxidation, the oxide layer is responsible for almost the entire voltage ${ }^{[5]}$. Since the current strength is nearly constant, the oxide layer resistivity to anodic current is $4-5$ times than the cathodic ore.

With the coating grows, the voltage-current curves change (Fig. 2). At an early stage before the spark stage (Fig. 2a, curve 1), polarization hysteresis is absent in both the anodic and cathodic half-periods. In the spark stage (Fig. 2a, curves 2), the slight polarisation hysteresis is most pronounced in the anodic half-period. In the cathodic half-period, the voltage-current curve is similar to that for the sparkless stage. The coating thickness varies slightly. Under steady micro-arc oxidation (Fig. 2b, curves 3), the hysteresis effects of anodic polarisation and cathodic conductivity are greatly amplified.

If the cathodic component of alternating current is absent, the micro-arc oscillograms show no characteristic second peak (Fig. 3).

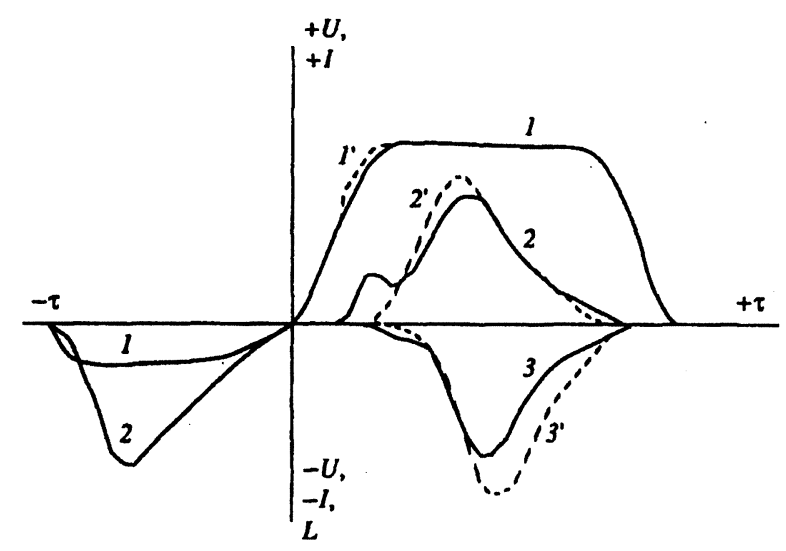

Figure 3. Variations in the values of $\left(1,1^{\prime}\right)$ instantaneous voltage, $\left(2,2^{\prime}\right)$ polarising current, and $\left(3,3^{\prime}\right)$ light intensity within one period of alternating current after $30 \mathrm{~min}$ oxidation: (1 - 3) AC mode; (1'- 3') without cathodic component.

Figura 3. Variaciones de valores instantáneos de la tensión $(1,11)$, de la corriente de polarización $(2,21)$, de la señal luminosa $\left(3,3^{\prime}\right)$, en un periodo de la corriente alterna dentro de $30 \mathrm{~min}$ de la oxidación: en corriente alterna (1 3); sin componente catódico (1' - 3').

Rev. Metal. Madrid 36 (2000) 
With no cathodic polarisation (DC mode), the peak values of the current and the light intensity are higher; so are the discharge voltage, ignition time, and power. However, the protective properties of the coatings degrade (Table III).

The coating properties largely depend on polarization (Table IV). Oxide thickness is maximum in the $\mathrm{AC}$ oxidation conditions. Keeping in mind that oxidation proceeds mostly in the anodic half-period, one should not expect a decrease in thickness in the DC conditions; however, a decrease was observed.

It should be noted that alloying of aluminium with copper, magnesium, and silicon substantially affects the electrical parameters of formation process and properties of the coatings (Table $\mathrm{V}$ ).

All other things being equal, the coatings on aluminium offer the best protective properties.

With roughly equal maximum voltages in anodic and cathodic half-period, alloying with copper and magnesium enhances discharge power dissipation. Alloying with silicon decreases the oxide thickness and chemical resistance. The Al$\mathrm{Mg}$ alloys exhibit much more intense light

Table III. Electrical parameters and properties of the coatings obtained on aluminium after 30 min oxidation

Tabla III. Características eléctricas y propiedades de los recubrimientos sobre aluminio durante $30 \mathrm{~min}$ de oxidación

\begin{tabular}{lcccc}
\hline Polarisation mode & $t_{\mathrm{ig}, \mathrm{ms}}$ & $U_{\mathrm{ig},} \mathrm{V}$ & $N_{\mathrm{dis},}, \mathrm{W}$ & $\tau_{\mathrm{ch.r},}, \min$ \\
\hline AC mode & 1.0 & 99 & 960 & 13 \\
DC mode & 2.9 & 183 & 1204 & 6 \\
\hline
\end{tabular}

Note: $t_{\text {ig }}$ the ignition time; $N_{\text {dis }}$ is the integral maximum discharge power; $U_{\text {ig }}$ is the ignition voltage; and $\tau_{c h . r}$ is the chemical resistance of the coatings.

Nota: $t_{i q}$ es el tiempo del encendido de la descarga; $N_{\text {dis }}$ es la potencia máxima integral en las descargas; $U_{\text {ig }}$ es la tensión del encendido de la descarga; $\tau_{\text {ch.r }}$ es la resistencia química de los recubrimientos.

Table IV. Properties of the coatings formed on 2024 alloy for $1 \mathrm{~h}$ oxidation

Tabla IV. Espesor y propiedades de los recubrimientos, tomados sobre la aleación 2024 durante 1 h de oxidación

\begin{tabular}{cccc}
\hline $\begin{array}{c}\text { Polarization } \\
\text { mode }\end{array}$ & $\begin{array}{c}\text { Thickness, } \\
\mu \mathrm{m}\end{array}$ & $\begin{array}{c}\text { Microhardness, } \\
\text { GPa }\end{array}$ & $\begin{array}{c}\text { Electric } \\
\text { strength, } \mathrm{V} / \mu \mathrm{m}\end{array}$ \\
\hline $\mathrm{AC}$ & 64 & 17 & 26 \\
$\mathrm{DC}$ & 40 & 9 & 14 \\
\hline
\end{tabular}

Table V. Electrical parameters of the polarisation and the coating properties upon oxidation under the $A C$ mode for $30 \mathrm{~min}$

Tabla V. Características eléctricas de la polarización y propiedades de los recubrimientos en la oxidación en régimen $A C$ durante $30 \mathrm{~min}$

\begin{tabular}{|c|c|c|c|c|c|c|c|}
\hline Alloy & $U_{a}, V$ & $U_{c}, \mathrm{~V}$ & $N_{\mathrm{dis}}, \mathrm{W}$ & $U_{\mathrm{ig}} \mathrm{V}$ & $L, \mathrm{mV}$ & $h, \mu \mathrm{m}$ & $\tau_{\text {ch.r, }} \min$ \\
\hline $\mathrm{Al}(99,6 \%)$ & 520 & 85 & 960 & 99 & 22 & 28 & 13.0 \\
\hline $\mathrm{Al}-5 \% \mathrm{Cu}$ & 510 & 70 & 1365 & 108 & 19 & 22 & 8.2 \\
\hline $\mathrm{Al}-3 \% \mathrm{Cu}-2 \% \mathrm{Mg}$ & 510 & 75 & 1530 & 68 & 22 & 27 & 6.4 \\
\hline $\mathrm{Al}-5 \% \mathrm{Mg}$ & 520 & 80 & 1550 & 83 & 32 & 27 & 7.8 \\
\hline Al- $5 \% \mathrm{Si}$ & 510 & 70 & 1050 & 82 & 18 & 14 & 5.6 \\
\hline
\end{tabular}

Note: $U_{a}$, and $U_{c}$, are the maximum voltages and minimum resistances in the anodic and cathodic half-period, respectively; $N_{\text {dis }}$ is the integral maximum discharge power; $U_{\text {ig }}$ is the ignition voltage; $L$ is the light intensity; $h$ is the coating thickness; and $\tau_{c h . r}$ is the chemical resistance of the coatings.

Nota: $U_{a}$ y $U_{c}$, son las tensiones máximas y resistencias mínimas en los semiperiodos anódico y catódico; $N_{\text {dis }}$ es la potencia máxima integral en las descargas; $U_{i g}$ es la tensión del encendido de la descarga; L es la intensidad de la corriente de luz; $h$ es el espesor del recubrimiento; $\tau_{c h . r}$ es la resistencia química de los recubrimientos.

emission during the process, than the alloys doped with silicon and copper.

Variations in the discharge intensity upon introduction of the dopants into aluminium indicate that they take part in the discharge process either as components of the alloy or as components being incorporated into the oxide.

The $\mathrm{X}$-ray diffraction analysis showed that, beside $\alpha$ - and $\gamma-\mathrm{Al}_{2} \mathrm{O}_{3}$, the coatings on the $\mathrm{Al}-\mathrm{Cu}$ alloys include a $\mathrm{CuAl}_{2} \mathrm{O}_{4}$ phase, those on the $\mathrm{Al}$ $\mathrm{Mg}$ alloys involve $\mathrm{MgAl}_{2} \mathrm{O}_{4}$ and, finally, the coatings on the $\mathrm{Al}-\mathrm{Si}$ alloys contain an $\mathrm{Al}_{2} \mathrm{SiO}_{5}$ oxide and also $\mathrm{AlSiOOH}$ and $\mathrm{Al}_{2} \mathrm{Si}_{2} \mathrm{O}_{5}(\mathrm{OH})_{4}$ oxyhydroxides. It was found that, unlike for the $\mathrm{Al}-\mathrm{Cu}, \mathrm{Al}-\mathrm{Mg}$, and $\mathrm{Al}-\mathrm{Cu}-\mathrm{Mg}$ systems, the oxidation of the Al-Si alloys does produce $\alpha-\mathrm{Al}_{2} \mathrm{O}_{3}$ high-temperature modification. The oxidation of the $\mathrm{Al}-\mathrm{Cu}-\mathrm{Mg}$ alloys results in coatings that consist of $\mathrm{CuAl}_{2} \mathrm{O}_{4}, \mathrm{MgAl}_{2} \mathrm{O}_{4}$ and $\mathrm{MgCu}_{2} \mathrm{O}_{4}$ phases.

Chemical and phase composition of electrolyte also influence greatly on the structure and properties of coatings being oxidized. Our experience suggests that oxidation takes place most effectively in colloid electrolytes with optical density of 2.1-2.3. Colloid particles stabilise the process and facilitate the formation of coatings of uniform thickness and no oxidation was observed in the fresh $\mathrm{NaOH}$. More coarse sediments provide 
rougher surfaces and deteriorate the coating. Thus, to maintain a steady operation, the electrolyte should contain colloidal aluminates.

The stability of the colloid system is determined by possibility of mergence of nuclei. Anions of phosphates and silicates are the surface-active substances. Their introduction into the aluminate solutions results in formation of stable colloid systems and may aid in the effectiveness of the process for transfer in the colloid particles to the discharge zone. As anions are adsorbed on the surface of the micelle nucleus, the aluminate and phosphate or silicate particles are simultaneously transferred to the discharge zone.

Introduction of finely divided powders of $\mathrm{CuO}$ and $\mathrm{MgO}$ into the oxidation electrolyte resulted in formation of spinel phases $\mathrm{CuAl}_{2} \mathrm{O}_{4}$ and $\mathrm{MgAl}_{2} \mathrm{O}_{4}$. But if the copper oxide forms the new phase in great amount, only traces of $\mathrm{MgAl}_{2} \mathrm{O}_{4}$ were noted on the roentgenograms obtained from the samples of coatings formed from the electrolyte containing the magnesium oxide. Such behaviour of the oxide powders may be explained by difference in melting temperatures between the copper and magnesium spinels.

Introduction of finely divided powders of lowmelting glasses into the oxidation electrolyte resulted in the formation of low-porous coatings. Fused phase containing mainly the glass material was concentrated at surface of these coatings. Oxidation speed increases approximately by $20 \%$.

\section{DISCUSSION}

It has been suggested ${ }^{[6}$ and 7$]$ that experimental rectification of the alternating current is caused by the space-charge region with essentially onedirection conduction. When a direct (in our case, cathodic) voltage is applied to a barrier, its conductivity is limited by the resistivity both of the oxide layer and of the gas-filled gap in oxide pores; with a reverse (anodic) voltage, the barrier conductivity depends on the resistivity of the space-charge region.

At an early (sparkless and spark) oxidation stages, a Schottky barrier at a metal-oxide interface may act as such a barrier. This barrier features virtually no relaxation process, because of the high concentration of major carriers in a metal. If the layer is not thick (sparkless stage), heat removals into the metal and electrolyte is intensive and a fine-pore material is produced whose pores contact the metal (Fig. 4-2a).

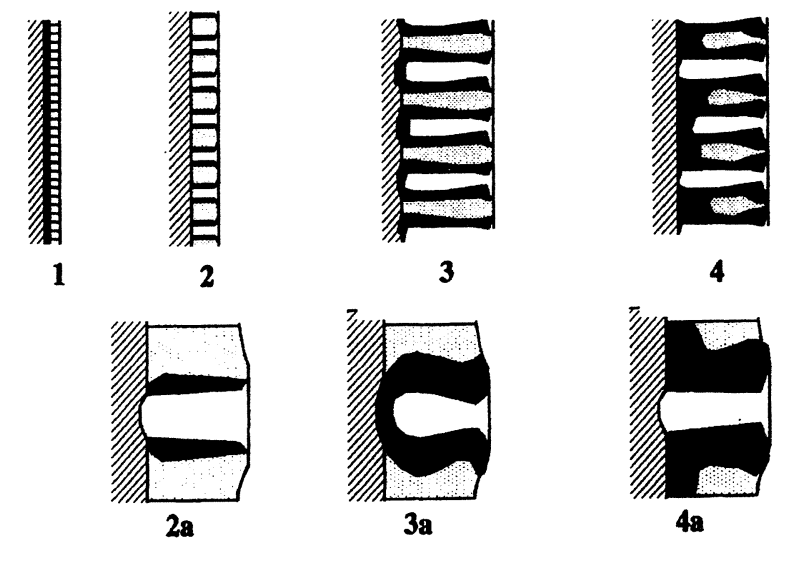

Figure 4. Alternating stages and structure changes in the coatings being oxidized during microplasma oxidation: sparkless (1); spark $(2,2 a)$; micro-arc $(3,3 a)$; and arc $(4$, 4a).

Figura 4. Cambio de etapas y de estructura de los recubrimientos oxidados por microplasma (1) - sin chispas; $(2,2 a)$ - con chispas; $(3,3 a)$ - micro-arco; $(4,4 a)$ - arco

The particles of $\mathrm{Al}(\mathrm{OH})_{3}$ formed due to the hydrolysis of aluminate solutions react with the aluminate alkaline solution. The aluminate ions are adsorbed by the surface of the aluminium hydroxide particles. Cations are distributed among diffusive and adsorptive layers of micelle:

$$
\left\{\left[\mathrm{Al}(\mathrm{OH})_{3}\right] \mathrm{n} \mathrm{AlO}_{2}^{-}(\mathrm{n}-\mathrm{x}) \mathrm{Na}^{+}\right\} \mathrm{xNa}^{+}
$$

Due to this fact, the aggregate is transformed into the sol state.

During the anodic half-period, the micelles with the nucleus from aggregates $\mathrm{Al}(\mathrm{OH})_{3}$ will move together with anions to the discharge channel. Under the action of an electric field, colloidal particles, which acquire a negative charge, tend toward the anode and settle partially on its outer surface and partially in the pores of the coating; the latter part of the particles are dehydrated by the Joule heat. In both cases, the particles are built in the oxide layer.

Anions, which contain aluminium, are drawn into the discharge channel and subjected to changes. One can imagine that the dehydration processes take place in the discharge channel under the action of the high temperature, for example:

$$
\begin{aligned}
{\left[\mathrm{Al}(\mathrm{OH})_{4} 2 \mathrm{H}_{2} \mathrm{O}\right]^{-} \stackrel{\mathrm{T}}{\rightarrow} \mathrm{Al}(\mathrm{OH})_{3}+\mathrm{OH}^{-}+2 \mathrm{H}_{2} \mathrm{O} } \\
\stackrel{\mathrm{T}}{\rightarrow} \mathrm{Al}_{2} \mathrm{O}_{3}+3 \mathrm{H}_{2} \mathrm{O}
\end{aligned}
$$


Besides, the thermal dissociation of polymeric anions may take place.

With time, the products of plasmochemical and thermochemical reactions that accumulate in pores can completely fill them. Pores are closed by fusing and open porosity decreases (Figs. 4-3a).

In this case, spark discharges will not finish on a metal surface but on a surface of the already formed oxide layer. This oxide layer consists mainly of the $\alpha-\mathrm{Al}_{2} \mathrm{O}_{3}$ high-temperature modification with inclusions in the form of a spinel-phase $\left(\mathrm{CuAl}_{2} \mathrm{O}_{4}, \mathrm{MgAl}_{2} \mathrm{O}_{4}\right)$.

Because of heating to high temperatures, diffusion processes in the oxide layer are facilitated. Its inner and outer boundaries become enriched with oxygen and metal, respectively. Negative and positive space-charge zones begin to form, and their contact features rectifying properties.

Thus, the sparking-to-micro-arcing transition takes place when a space-charge region separated from a metal-oxide boundary arises in a coating.

Because the coating regions that generate the discharges grow at a certain moment voltage may break down the entire coating and the system will change to the arc oxidation stage (Figs. 4-4a).

An increase of polarisation hysteresis within the micro-arc stage (Figs. 2-3) may serve as indirect evidence for the shift of the space-charge deep into the oxide. In fact, in the semi-conducting oxide phases (namely, a heated aluminium oxide coating) depletion layers wider than a Schottky barrier are formed, due to a lower carrier concentration $^{[8]}$. Moreover, under blocking conditions, this layer widens further and a subsequent switching of direct voltage causes a relaxation, during which the resistivity of the system is again increased ${ }^{[8]}$.

The cathode current narrows the space-charge layer in the oxide film and, upon subsequent transferring to the anodic half-period, the conductivity of the system remains increased. Accordingly, the ignition time and voltage decrease.

It is generally considered that the anodic removal of electrons from the space-charge region to the metal depletes the region of charge carriers, increasing the potential barrier, and hence the resistivity. This causes the voltage to increase and thus, the total power of the plasma microdischarges also increases. Under these conditions, the fraction of fused material is higher and the emission of metals, oxides and gases to the electrolyte is enhanced, decreasing the current yield. The increased porosity of coatings produced in the DC mode is evident in the low electric strength (Table IV).

Cathodic polarisation in the AC mode decreases the space charge and lowers the associated potential barrier, thereby facilitating electron transfer through the oxide layer and hydrogen evolution at a pore bottom. Under such conditions, electrolyte alkalisation will serve to accumulate soluble aluminium hydroxocomplexes in the solution. Hydrogen evolved can also partially reduce the oxidation products.

The anodic part of the period, which follows the cathodic one, starts under increased oxide conductivity and an excess of hydrogen remaining in a discharge channel. Hydrogen increases the plasma temperature and facilitates the transformation of the mentioned hydroxocomplexes to hydroxides and then to oxides.

Thus, the cathodic polarisation not only facilitates the following anodic oxidation, but also contributes to the growth and melting of the oxide coating.

The incorporation of the alloy constituents into the coatings should necessarily affect their electrophysical properties, thus changing the electrical parameters of the process. A difference in the latter may be indicative of the fact that different width of a depletion space-charge layer is characteristic of the coatings formed on various aluminium alloys, depending on the dielectric properties of the material and, in particular, on the concentration of major carriers. Therefore, it can be concluded that the oxide layer formed on aluminium affords the best dielectric properties among those coatings listed in table V.

\section{CONCLUSIONS}

- A spontaneous sequence of the sparkless, spark, micro-arc, and arc stages of the process is accompanied by modifications of the structure of the coating and conditions for microplasma discharges. At the same time, to obtain the coatings with the best properties micro-arc stage is advantageous.

- To obtain more dense, hard, protective coatings, the use of alternating current is preferable. It has been found that the cathodic component of the AC changes the space-charge layer in the oxide.

- The presence of colloidal particles in electrolyte is important for microplasma deposition 
techniques. The electrolyte particles which can form the polymeric compounds with metal get into the structure of the oxide layer and may considerably change the properties of coatings. Introduction of polyphosphates into the alkaline electrolyte makes it possible (all other factors being equal) to form coatings on the aluminium alloys which present higher mechanical and physicochemical properties.

\section{REFERENCES}

[1] A. Gunterschulze and H. Betz, Z. Phys. 78 (1932) 196-210.

[2] A. Gunterschulze and H. Betz, Z. Phys. 91 (1934) 70-96.
[3] G. A. Markov, V. M. Belevantsev, A. M. Slonova and O. P. TERLEEVA, Elektrokhimiya 25 (1989) 11, 1473-1479.

[4] S. G. Alieva, M. B. Al'tman, S. M. Ambartsumyan et al., Promyshlennye Alyuminievye Splavy: Spravochnik (Industrial Aluminium Alloys: A Handbook), Metallurgiya, Moscow, 1984.

[5] W. MCNeILL and L.L. GruSs, J. Electrochem. Soc. 110 (1963) 853-855.

[6] A. V. Timoshenko, S. Gut, B. K. Opara et al., Zashch. Met. 30 (1994) 149.

[7] A. V. Timoshenko, B. K. Opara and Fam Van Min', Abstracts of Paper Nauchno-Tekhnicheskii Seminar Anod-88, Kazan, 1988, p. 75.

[8] G. I. EpIFANOV and Y. A. MOMA, Tverdotel'naya Elektronika, Vysshaya Shkola, Moscow, 1986. 